\title{
Dynamisms of Financialization Circuits of Power in Globalized Production Networks
}

Pedraza-Acosta, Isabel; Mouritsen, Jan

Document Version

Accepted author manuscript

Published in:

Human Relations

DOI:

$10.1177 / 0018726717751612$

Publication date:

2018

License

Unspecified

Citation for published version (APA):

Pedraza-Acosta, I., \& Mouritsen, J. (2018). Dynamisms of Financialization: Circuits of Power in Globalized

Production Networks. Human Relations, 71(6), 845-866. https://doi.org/10.1177/0018726717751612

Link to publication in CBS Research Portal

\section{General rights}

Copyright and moral rights for the publications made accessible in the public portal are retained by the authors and/or other copyright owners and it is a condition of accessing publications that users recognise and abide by the legal requirements associated with these rights.

Take down policy

If you believe that this document breaches copyright please contact us (research.lib@cbs.dk) providing details, and we will remove access to the work immediately and investigate your claim. 


\section{Dynamisms of Financialization: Circuits of Power in Globalized Production Networks Isabel Pedraza-Acosta and Jan Mouritsen}

Journal article (Accepted manuscript*)

\section{Please cite this article as:}

Pedraza-Acosta, I., \& Mouritsen, J. (2018). Dynamisms of Financialization: Circuits of Power in Globalized Production Networks. Human Relations, 71(6), 845-866. https://doi.org/10.1177/0018726717751612

\section{DOl: https://doi.org/10.1177/0018726717751612}

Copyright (C) The Author(s) २०18. Reprinted by permission of SAGE Publications.

* This version of the article has been accepted for publication and undergone full peer review but has not been through the copyediting, typesetting, pagination and proofreading process, which may lead to differences between this version and the publisher's final version AKA Version of Record. 


\title{
Dynamisms of financialization: Circuits of power in globalised production networks
}

Isabel Pedraza-Acosta and Jan Mouritsen

\begin{abstract}
This paper analyses the dominant ideological mode of rationality of financialization, its operationalisation via accounting devices and deployments in political intra- and interorganisational processes, and its dynamisms in global production networks. It asks how are political processes informed and conditioned by calculative devices that mediate financialization processes? Drawing on a study of a French multinational corporation (MNC) whose accounting devices - one concerning performance which requires suppliers to be 'poor' and another concerning risk which requires suppliers to be 'rich' - the paper focuses on the dynamic of circuits of power. Accounting devices provide one-sided incentives by categorising suppliers as costs, silencing the industrial rationality of the network where suppliers are the capabilities and skills needed by the MNC. Such tensions put the network at risk, as when the suppliers went bankrupt, the MNC was devoid of its industrial competencies.
\end{abstract}

Financialization is ambiguous. Its devices are not inherently facilitative of systemic powers but reflect an ideological mode of rationality and political processes that produce overflows. The associated circuits of power show that systemic power is never eternal but dynamic. Circuits of power develop ambiguous political processes that push disruptive dynamisms of financialization processes in global production networks. Financialization produces costly tensions.

Keywords: accounting; calculative devices; dominant ideological modes of rationality; financialization; global production network; multinational corporations; MNC; political processes; risk 


\section{Introduction}

Financialization is a dominant rationality that drives the dynamics of global production networks (Coe and Yeung, 2015; Epstein, 2005; Sawyer, 2013; Van der Zwan, 2014) and has created an international division of labour based on the power of financial resources (Froud et al., 1998, 2014; Palpacuer et al., 2011). However, certain questions remain. How does a financial economy operate at the firm level? How does it wield power? The literature has begun to investigate managerial power (Andersson et al., 2007; Mudambi and Navarra, 2004) and political strategies in headquarter-subsidiary relationships (Becker-Ritterspach and Dörrenbächer, 2011; Blazejewski, 2009; Bouquet and Birkinshaw, 2008; Dörrenbächer and Geppert, 2009; Levy, 2008; Morgan and Kristensen, 2006). Focusing on interactions, scholars generally understand such relationships as bodily embedded. However, calculative devices - 'objects with agency' (Muniesa et al., 2007: 2) - that sustain the continuity of power relations receive less attention. Indeed, the literature has focused more on interpersonal politics than on the technical mechanisms that render dominant ideological rationalities operable and durable in global production networks.

This paper seeks to explore how a dominant rationality such as financialization is made operational and deployed in political games. Operationalisation happens both as the social and organisational categorisation of human actors and organisations, and by attributing value to these categories via accounting and other calculative devices. Although political games occur in episodes, they are realised in relation to rationalities that tie episodes together. On one side, categorisation is important because it assigns specific social positions to people and organisations, and on the other, accounting devices help imbue categories with certain financialized rationalities and values, thus provoking specific organisational conduct (Cooper and Ezzamel, 2013; Ezzamel 
et al., 2008; Froud et al., 2006; Morgan and Kristensen, 2006; Piotti, 2009). Accounting devices are particularly relevant for understanding translations between the macro- and micro-politics of financialization, because they make translations durable and actionable at a distance (Cerny, 1997; Clegg et al., 2011; Gill, 1995; Piven and Cloward, 1997; Ruigrok and Van Tulder, 1995). Thus, the research question concerns how political processes are informed and conditioned by categorisation and accounting devices that mediate financialization processes at both the level of the global production network and the intra-organisational level of a multinational corporation (MNC).

Drawing on the idea that categorisation and accounting devices are related to key circuits of power (Baunsgaard and Clegg, 2012), this paper explores how a French MNC framed its relationships with its suppliers through two main types of accounting devices related to performance and risk, respectively. Performance was operationalised as a continuous drive to reduce costs, and risk was operationalised as the probability of supply-chain disruptions caused by the suppliers' potential bankruptcy due to their poor financial performance. This rationality weighted the MNC's financial concerns. As the case study will show, those financial concerns tended to be oriented towards capturing value, which, however, built risk by neglecting the industrial mode of rationality concerned with interdependencies, technology, innovation and skills. Performance requirements pushed suppliers into accepting high levels of risk. In a strange twist, the success of financialization practices challenged the suppliers' sustainability, and in turn, the French manufacturer's global production network was put at costly risk.

The following section discusses the literature on political processes in global production networks. Stewart Clegg's framework of circuits of power is the lens proposed for understanding the roles of accounting devices within circuits of power. The empirical setting is then presented 
and the paper discusses the role of categorisation and accounting devices in an MNC's relationships of power when its financialized systemic and dispositional powers confronted the competing, but hidden, industrial rationality of the network in which it operated.

\section{Politics in global production networks}

It is common to conceptualise MNCs as inter-organisational networks 'embedded in an external network consisting of all the other organisations with which the different parts of the multinational have to interact' (Ghoshal and Bartlett, 1988: 365). A MNC is a 'network orchestrator' (Parkhe and Dhanaraj, 2003) and 'through their decisions on how to organize value chains at the global level, firms generate multiple socio-economic impacts in the countries where they invest (both directly and through outsourcing strategies). They shape opportunities and hurdles for suppliers to upgrade, while also facing the risk that successful functional upgrading turns suppliers into potential competitors' (De Marchi et al., 2014: 479). Consequently, MNCs' boundaries extend beyond their legal delineations (Holm et al., 2005), increasing the level of value chain interdependencies — and vulnerabilities — among agencies.

Interdependencies and vulnerabilities seed the potential for conflicting political processes. One possibility is the rational type of micro-politics that, through agency theory, ascribes different but alignable interests to principals and agents in the agency relationship. Mudambi and Navarra (2004) theorise headquarter (HQ)-subsidiary relationships as principal-agent relationships, and micro-politics is understood as the propensity of subsidiaries to become self-serving 'as a defensive reaction to rent-seeking by headquarters' (Mudambi and Navarra, 2004: 386) against relations between top managers and owners which are aligned through financial mechanisms such as stock options (Goyer, 2001; Morin, 2000). Nevertheless, this financialization of organisational 
relationships deepens the disconnection of member categories, such as top management and labour, and the disconnection from production concerns in local markets (Boyer, 2005; Froud et al., 2000). Bouquet and Birkinshaw (2008) suggest that HQ-subsidiary bargaining power is related to actors' network centrality and control over resources. This relationality focuses on strategies of co-optation, representation and coalition building, all of which involve building potentially antagonistic relational positions within global production networks. As Morgan and Kristensen (2006) argue, this network positioning and reordering of control over resources requires some measure of ability to act at a distance through various devices, many of which are operationalised via accounting calculations:

'For the senior managers of multinationals ... various and often changing benchmarks become the means for senior managers to judge performance across sites and to leverage local managers and employees to higher levels of performance. It is at this point that subsidiary managers receive these pressures and evolve their responses' (Morgan and Kristensen, 2006:1482).

At this juncture, political processes between HQ and subsidiaries likely involve suppliers in global production networks. Research has primarily focused on the consequences of HQsubsidiary power dynamics on the management of (local) production networks (Andersson et al., 2007). However, political processes are not just episodically relational; they are also embedded in institutional reproduction (Becker-Ritterspach and Dörrenbächer, 2011). The institutional reproduction of political processes concerns how 'forms, outcomes, and dynamics of economic organisation (firms, networks, markets) are influenced and shaped by other social institutions (e.g., training systems, legal systems, political systems, educational systems, etc.)' (Heidenreich, 2012: 565). Here, power is related to hierarchical positions (Pettigrew et al., 2003), professional 
backgrounds (Fligstein, 1993) and social capital (Kostova and Roth, 2003). Combinations of various institutional resources are understood to shape agencies' strategising activities and negotiation strategies in pursuit of career ambitions (Dörrenbächer and Geppert, 2009: 108) through the 'politics of intra-firm competition' (Becker-Ritterspach and Dörrenbächer, 2011). This institutional view focuses on 'certain psychological states, perceptions, and behavioural expectations that social agencies form as a result both of their being part of social structures and the nature of their relationships in these structures' (Becker-Ritterspach and Dörrenbächer, 2011: $301)$.

The HQ-subsidiary political processes considered in the literature cannot be separated from wider on-going processes of financialization, because many contradictions arise from managers' concerns directed at restructuring and reordering the firm to capture value based on the demands of capital markets (Froud et al., 2000, 2006, 2014). Accounting is one particularly interesting device because it articulates abstract notions of performance at all levels and in all situations in which middle managers may be set against one another (Cooper and Ezzamel, 2013; Ezzamel et al., 2004a, 2004b, 2008; Mueller, 1996; Mueller and Purcell, 1992). For instance, when accounting numbers are used to rank managers, political games tend to focus attention on people's movements within and across hierarchies, sometimes in contrast to attention towards matters involving the rationale of the type of industry in which the MNC is operating. ${ }^{1}$ Such political processes concern the circulation and mobility of people in their attempts to reach higher echelons of the firm and fuel attempts 'to put the best light on one's own achievements and move on before longer-term problems might emerge' (Morgan and Kristensen, 2006: 1477). Therefore, MNCs may become 'battlefields' (Kristensen and Zeitlin, 2001) in which political processes between agencies are organised according to the range of dominant meanings and goals produced and reproduced by 
means of devices found in performance measures developed by accounting systems (Cooper and Ezzamel, 2013; Miller and Power, 2013; Quattrone and Hopper, 2005). In general terms, the rules fixed by accounting facilitate broader techniques of discipline and the reproduction of dominant financial-ideological modes of rationality to flow through global production networks. However, given that financialization empowers some agencies to the detriment of others, it provides resources for political processes and conflict. It is unlikely that this process will result in an unproblematic equilibrium (Clegg, 1989: 215); indeed, it is more likely that the reproduction of the firm's dominant ideological mode of rationality might undermine its own agenda (Courpasson et al., 2012).

Moreover, political processes occur not only within MNCs but also within their increasingly diverse global production networks, which tend to use benchmarking and performance mobilised by accounting devices to increase global management (Morgan, 2011). Such developments find expression in the processes of appropriating and distributing value (Bair, 2009), in which agencies influence outcomes by exercising their 'buyer-power', e.g. by establishing product specifications, standards, logistics, volume, etc., or their 'normative power', e.g. by shaping expectations regarding how business should be organised or how quality should be assessed (De Marchi et al., 2014; Ponte and Sturgeon, 2014). Therefore, global production networks allow less space for market competition or value-adding chains and more space for 'complex political economic systems in which markets - and their associated distribution of resources and authority - are constructed within and actively shaped by their socio-political context' (Levy, 2008: 943). Thus, , global production networks are contested inter-organisational fields in which agencies struggle over the construction of economic relationships, governance 
structures, institutional rules, and norms and discursive frames (Hardy et al., 1998; Maguire et al., 2004).

\section{Dominating rationality, categorisation and framing}

Clegg's (1989; Clegg et al., 2006) theory of circuits of power relates episodic power, dispositional power and facilitative power. Through episodic processes, agencies deploy strategies and negotiate circumstantial organisational rationalities that will reproduce or transform rules of practice. Dispositional processes of power inform and condition central agents' developments and interpretations of rules of practice, which are applied by mechanisms of facilitative power. Such processes are underwritten by a dominant ideological mode of rationality being 'an overwhelming mentality that penetrates an organisation or parts of it, and provides meaning in a more or less conscious manner to its members so vigorously that social practice is primarily based on it. Such practices, in turn, influence processes recursively related to it' (Baunsgaard and Clegg, 2012: 206). This conceptualisation of dominant rationalities echoes Foucault's 'regimes of truth' (1981), in which 'subjectivity is designed as something that creates, assembles and transforms the relations it has with its own truth ... The truth is designed essentially as a system of obligations, regardless of the fact that from any point of view one can regard it as true or not true' (Foucault, 1981: 134). Dominant rationalities help fixing the relations of meaning and membership mobilised in social practices such as members' categorisation activities discipline meanings, relations and memberships (Clegg, 1989: 205; Baunsgaard and Clegg, 2012). They are 'those categories in the language in terms of which persons may be classified. For example, the categories: 'male', 'teacher', 'first baseman', 'professional', 'negro', etc.' ('Sacks 1966: 15; Sacks, 1972). Such categories are understood as 'normal to use in constituting their sense of the world ... (they are) 
discursive devices of legitimacy ... (that) deliver the particular meaning of specific dominant modes of rationality as they are wrapped in specific projects ... they sustain specific power relations and rationales for action' (Baunsgaard and Clegg, 2012: 208-209). Such an 'identitygiving' connotation highlights how different agencies are empowered or disempowered by this categorisation process. Thus, categorisation is not a single act, but part of the on-going creation of rules of practice that express how 'ideology objects are mobilized in and made material by specific techniques of power' (Sacks 1966: 9).

In Clegg's model, categorisation devices are key components in the dispositional circuit of 'social integration' in which 'rules of the game' and stabilised meanings and memberships are fixed or re-fixed through social integration (Clegg, 1989: 233), which gradually solidify and become stronger through their continual application in the intersection of strategies of power, dominant rationalities and practices. They are constituted of 'those rules and techniques that have succeeded in becoming fixed within the network' (Oliveira and Clegg, 2015: 443). In other words, several processes can be expected to occur at the intersection of the episodic and dispositional levels of circuits of power.

Considerations about such processes bring questions about techniques of power, typically embedded in administrative arrangements of facilitative power. Callon et al. (1986) and Latour (2005) repeatedly stress how the substantial activity of devices often underwrites such arrangements and makes society durable (Latour, 1991). When a device 'works', it bends the world around it. It does not have intention like that of humans, but it may help stretch power when it can force others - both humans and non-humans - out of their way.

As conduits of power, devices help produce durability. There are many types of devices including not only material technologies, such as production machinery and physical materials, 
but also visualisation technologies, such as accounting, that inscribe the world and enhance its visibility in certain respects, making action at a distance possible (Latour, 1986). These devices are important because firms use them en masse (Ezzamel et al., 2004a). They visualise dominant rationalities by framing them, that is, by allowing those rationales to be present in a particular form. This framing, however, is incomplete and partial. Devices, even when they confer meaning and subjectification, do not contain the complexities of the entire world because they frame only parts of it. As Callon (1998: 255) says, 'framing . . ensures that certain courses of action are followed and at the same time generate externalities; this costly framing process is necessarily incomplete: first, because a wholly hermetic frame is a contradiction in terms, and second, because flows are always bidirectional, overflows simply being the inevitable corollary of the requisite links with the surrounding environment.' Therefore, it is not only possible but also likely that the coordination expected by framing is challenged by overflows, things that 'cross or break through' (Callon, 1998: 256) the boundaries of the frame and which have positive or negative consequences, especially for entities outside the frame. A typical example of overflow is the activity of a chemical plant poisoning a neighbouring village via their emissions of toxic fumes. ${ }^{2}$ Evidently, overflows will then orbit around their associated controversial forums in which heterogeneous circuits of power could become enmeshed. In other words, framing produces boundaries by separating some things from other things, providing each with an independent status such that they stand out as coherent and different from their external features. This distinction between the inside and the outside creates clarity, reduces ambiguity and enables decision-making, since framing priorities are more important than other matters. Framing produces clarity and focus and frees action from its complex context. However, the crucial point is that even if action may be freed from its context, 
the effects of that action cannot be freed from the context that the framing has placed outside of its boundaries. Therefore, overflows become the rule rather than the exception.

The following study of the French MNC, Mondialmaker, shows that the power of financialization is contradictory. With its dominant mode of rationality made operational by the framings constructed by accounting devices, it wants to extract rent from suppliers by putting

pressure on costs, but neglecting that suppliers' potential insolvency would threaten the viability of the entire global production network, which the MNC operates. In this case, financialization neglects the industrial mode of rationality in the form of technology, skills and capabilities that dominates Mondialmaker's global production network operations.

\section{Methods and methodology}

The study of Mondialmaker, a French manufacturer, focuses on the operationalisation of the dominant financial-ideological rationality into calculative devices and their informing and mediating role in circuits of power of a global production network. It examines how 'ideology objects' are constructed, and mobilised in and made material through specific power techniques contained in managerial disciplines of accounting (Clegg et al., 2011).

The empirical field research was conducted as an ethnography, which drew on interviews, observations and analyses of MNC archives on internal control documents. These sources of evidence were used because power is enacted via practices, techniques and procedures (Townley, 1993). Data collection occurred primarily during and after the economic crisis of 2009, which revealed tensions of the system of action more clearly, issues, ideas and processes that 'normally', as Wieviorka (2009) notes, are invisible. 
The overall research methodology aims at capturing the various dynamics of circuits of power. Seven months were spent at the HQ of Mondialmaker. We were based at a desk in the purchasing department, where immersion was facilitated as the entire floor was organised as an open-plan office. From the beginning, we were authorised to explore the firm's intranet. Our presence on-site allowed us to participate in informal relations of episodic power. During the first enquiry phase, we were authorised to attend any meetings we considered helpful in terms of understanding how risk and performance devices were used in everyday operations and strategic sourcing decisions.

Overall, 53 interviews were conducted from 2009 and 2011 within Mondialmaker and with three of its strategic suppliers and non-government and regulative authorities. They were reflexive (Alvesson, 2003) and analytical (Kreiner and Mouritsen, 2005) interviews. We began with broad interviews and then moved on to more focused interviews about political processes within the MNC's global production network. The interviews were conducted in three rounds to illuminate how risk and performance devices were used in strategic sourcing decisions, and how accounting devices and dynamic relations of episodic power resulted in overflows during critical times. To narrow the focus of the study, these interviews focused on outsourced components made by strategic suppliers that were already facing financial difficulties. The data analysis began at the end of the exploratory phase and continued with the second round of interviews, which also allowed us to collect more specific tags as well because it contributed to the collection of more specific documents so that we could code our primary and secondary data. The third and last round of interviews was done one year after the seven months of fieldwork. They contributed to following up on the developments of the coded outcomes of formally considered political processes. 
Understanding, structuring and delineating circuits of power within the focal firm not only required insight into the network of interdependencies that were recognised by the organisation but also the interdependencies created within the relationships of episodic power. We therefore analysed the supply risk files of the chosen strategic suppliers and the associated use of accounting devices that gave the relationships a sense of empowerment/disempowerment.

\section{Financialization as a dominant ideological mode of rationality in Mondialmaker}

From partners' suppliers to manufacturers' competitors

During the 1980s, when the industry was still highly vertically integrated, major manufacturers massively outsourced engineering activities and intermediate production activities. This initiated a double movement of concentration and specialisation of manufacturers to focus on downstream sources of growth and added value. During the 1990s, strategic responses to competition revolved around two axes: lower prices through cost control and differentiation through marketing. The costly differentiation and innovation efforts motivated manufacturers to transfer increasingly complex processes to their suppliers. Suppliers began to take charge of marketing, innovation and technological activities, not just production and the delivery of components. Economic performance through economies of scale was built not only from final growth but also from pressures on suppliers, who were forced to increase their competitiveness. Over the past decade, competition intensified so that manufacturers engaged in the redesign of their supply chain at different levels. First, they categorised suppliers according to their strategic importance so that strategic suppliers maintained close interactions with their manufacturers, particularly in the development phases of high value components in which they were fully responsible for providing technical modules ready for the assembly of complex products. These 
interactions remained hierarchical since the manufacturer defined and modified the volumes and prices of components so that the suppliers' financial returns were volatile. This context perpetuated and intensified traditional tensions in which each party sought to maximise its own financial benefits, even at the expense of the manufacturer, because suppliers were increasingly aware of the clients' risks and costs that would be associated with their disappearance.

\section{Mondialmaker's strategic change}

Mondialmaker was created at the beginning of the 19th century and was known for the outstanding performance of its products. Before 1980, Mondialmaker's brand strategy was focused on its customers' loyalty. Since 1990, Mondialmaker's customer segments and margins have been under pressure, with the result that the firm concentrated its strategic efforts on improving its overall economic performance.

From 2000 onwards, with the arrival of a new CEO labelled by the press as a 'cost killer', the firm focused on the establishment of production sites and commercial activities in emerging markets. The new CEO's strategic change aimed to shift the 'civil servant' style of management in the late 1980 s to a more 'entrepreneurial' style of management, which mainly translated into key performance objectives linked with employee bonuses and work evaluation. Furthermore, from 2010, purchasing strategies were changed and rules fixing memberships distributed decisionmaking power in such a way as to create intense and ambiguous relations of episodic power once actors had to make strategic sourcing decisions.

Free cash flows as a measure of value creation 
By 2010, this entrepreneurial method of management focused on economic performance as a core of Mondialmaker's strategy. Financialization was adopted and enacted by a set of accounting devices (key performance indicators [KPIs]), risk rating and profitability accounting) that framed financial performance more than industrial interdependencies, innovation and technological strategies of the global production network. This focus was underlined more intensely as Mondialmaker's strategy shifted in matters of free cash flows: 'To achieve our growth objectives and free cash flow, we will rely on leverage points such as our (innovation) expenditures and investment optimization, reducing costs ... and accelerating our international growth. Generating free cash flow is a condition', Mondialmaker suggested in an internal report. During the 2009 crisis, Mondialmaker's management teams increasingly stressed that value creation involved free cash flows, or as it was communicated internally, 'The operating cash flow minus capital expenditures measured the level of free cash flows; that is, the measure of value created'. This focus increased the return on equity by $30 \%$ annually over the course of five years from 2009 to 2014 , along with free cash flows that reduced the cost of capital by $1 / 3$ annually for some time.

In 2010, a presentation from Mondialmaker's intranet showed operating margin goals as $30 \%$ of the reduction of production costs, which was primarily based on reductions in the costs of purchased components. As mentioned in the preceding section, these overall top-down goals were resolved through outsourcing innovation and strategic production to suppliers where Mondialmaker's return on invested capital (ROIC) was the obligatory passage point. Thereby relationships of episodic power concerned with sourcing decisions had to pass a financial hurdle that suggested improving free cash flows. This was not only by increasing operational margins but also by economising on investments. 
Free cash flows were controlled by agencies operating through the global production network. These agencies complied with the meanings and membership rules of financial rationality, where the outcomes of relationships of episodic power reduced the amount of capital invested without decreasing the return on this capital. In other words, by mediating political processes, accounting devices gave 'the material conditions of techniques of production and discipline' (Clegg, 1989: 224) of financial rationality to the point they framed the supply relations within the network. They did so in a manner that empowered the agencies concerned with the stabilisation of the dominant financial rationality. More specifically, one device involved performance, the other risk.

\section{Performance management devices at Mondialmaker}

Performance devices at Mondialmaker aimed to reduce the costs of sourcing, innovation and production at every stage of the global network. This device measured the performance of Mondialmaker's purchasing, engineering, quality and financial agencies. It consisted of a series of calculations - or KPIs - that framed sourcing activities and made them visible in financial terms through a target-costing process that started from financial objectives and then pressured operations to find ways of honouring them. This pressure made the network an effect of the financial drive rather than a condition for financial results to develop. For example, the KPI Purch suggested that purchasing managers focus on continuously increasing suppliers' productivity in low-value components. Consequently, purchasing agencies were made responsible for exercising control over suppliers. The KPI Eng required cost savings through technical improvements of innovations, such that engineers would have to find ways to reduce costs by re-designing old parts - instead of designing new ones - so that supply negotiations would be eased because they would 
be based on known costs. Consequently, engineering agencies were made responsible for validating sourcings of high-value components. Corporate controllers were concerned with the KPI Comm, which focused on sales costs. Because sourcing costs accounted for $75 \%$ of the product net revenue, this component was key for corporate controllers. Consequently, corporate controllers had to mind products' budgeted sales costs. These relatively simple calculations reproduced and stabilised relations of episodic power within Mondialmaker. Performance devices constituted the techniques of production and the discipline of dispositional power. A quality manager explained how the performance device was pervasive in engineering:

'Engineering is given a budget as low as possible always . . it is normal. Mondialmaker manages by economising engineering's resources ... No, what I mean by that is that if you ask an engineer what resources he needs to do what we ask, he comes up with an unrealistic figure!'

Costs were aspirational instead of descriptive. Historical costs were always worse than those expected in the future. In this context, conflicts between engineers and corporate controllers were endemic. A purchasing manager explained how relations of episodic power were intensified by the contradictions among KPI goals:

'For a selling price, you have the engineer in charge of the (product) who is responsible for the ... operational margin. Then, you have the local purchasing manager who is responsible for the profitability of his region. Then, you have the controller who is responsible for the cost of sales. Therefore, you have three different performance objectives, each with a 
different logic, all of which contradict one another. Therefore, despite the same general objective of economic performance, they do not have the same performance objectives.'

Such relationships were fed by contradictions amongst KPIs. Tensions often involved the realism of cost objectives. Historical costs would be ambiguous bases for predicting sourcing costs because it was difficult to evaluate re-designed and new parts.

Although Mondialmaker's employees were sceptical about the performance devices, they accepted them. The dominant financial-rationality enabled discipline to the point where it was understood as normal. An engineer explained:

'There was a clear commitment of the firm to individualise the objectives with adverse effects ... obviously! .. . You know that everyone has their own personal interests ... what Mondialmaker hopes is that ... there cannot be a despot who decides for everyone; there are opposing powers everywhere ... And suddenly Mondialmaker thinks that it has the least bad situation for the company. I do not think it is at all stupid! But, this system generates a substantial waste of energy because everyone is acting against one another! . . . and very intense fights can break out!'

Agencies had to negotiate cooperation using multiple resources, such as knowledge, control over organisational understandings and information. One resource used by managers to achieve KPI objectives was to increase sourcing efficiencies by pressuring suppliers for constant price reductions. Notably, one engineering manager reflected on these practices by expressing his 
concerns about Mondialmaker managers who 'know that suppliers have to make a margin to survive but they tend to leave this aside.' The dilemma was that, on one hand, suppliers could be categorised as cost entities, but on the other hand, it was also clear that managers were sceptical about their reasonableness, and in so labelling them, expressed another potential, hidden categorisation in which dependency on supplies would be considered. However, social categorisation was strengthened by the divisions enacted by performance devices.

\section{Risk devices at Mondialmaker}

One implication of the use of performance devices at Mondialmaker was the constant pressure on suppliers' costs. Mondialmaker's management knew that this made suppliers financially vulnerable and could result in the disruption of its global production network. The disruption might occur due to suppliers' poor quality, longer production cycles and/or, most critically, financial collapse. Therefore, Mondialmaker framed the risk of supply-chain disruption. It did so primarily through the enactment of financialization modes of rationality that enabled agencies to transform risk into a set of financial ratings, focusing on the risk of suppliers' bankruptcy rather than, say, innovation and quality risk.

Financial risk agencies in charge of rating the suppliers' bankruptcy risk applied a series of accounting measures to gauge liquidity and credit performance. They used the suppliers' financial statements and financial market information from Bloomberg reports and from other well-established market and financial information sources, such as Dunn and Bradstreet scores (payment history and payment trends), company watch scores (a firm's financial health compared to similar companies that have failed) and the Altman z-score (the probability of bankruptcy based on accounting ratios). The financial risk agencies then combined these elements into a single rating 
ranging from one to four, which defined the level of risk that the supplier represented for Mondialmaker. Only those suppliers with the two highest ratings (one or two) could obtain highvalue component orders. Suppliers with a three or four rating would not be considered for highvalue component orders without authorisation from a supply risk committee. Some of these situations will be analysed below via exposition of Mondialmaker's relationships with one of its strategic suppliers, Globastic, who was facing immediate financial default.

\section{Circuits of power and the story of a struggling supplier}

The key difficulty in Mondialmaker's relationships with Globastic was that performance and risk devices contradicted each other: they were consistent with financialization only if the hypothesis of efficient markets, where suppliers could be easily substituted, was in place. The contradiction was that in order to fulfil Mondialmaker's financial demands, suppliers would have to be highly specialised in their clients' manufacturing activities but as low-cost producers. However, due to the reduced size of the market, if market demand decreased, suppliers were exposed to bankruptcy, and Mondialmaker would be exposed to supply disruptions in turn. The dominant rationality of financialization pursued through Mondialmaker's sourcing strategies made

managers the controllers of suppliers at a distance rather than managers of production and innovation. This social categorisation made suppliers objects rather than subjects of production networks, but surprisingly, this put Mondialmaker in a vulnerable situation since this mechanism emptied out its own competency in production matters via outsourcing. A quality manager explained: 
'When you externalised your expertise ... you become relatively weak in production techniques although you are technically competent ... But because you are relatively weak in parts production techniques, you need a supplier who is accustomed to your mode of operation; otherwise you cannot supervise them!'

As the financialization mode of rationality expanded, Mondialmaker pursued the externalisation of its expertise (as described above), while still wishing to control the resulting outsourced tasks, but suppliers became aware of their power over Mondialmaker from their innovation and production capabilities. In this sense, Mondialmaker moved from an innovationcentric organisation to one focused on ruling others through financialized devices. This attention to financial rather than industrial concerns was clearly sensed by one manager of Globastic:

'They are gradually suffocating us! They are leaving us absolutely no resources! ... First, this is a system in which buyers are people who are there for a short period . . . and they (have) an objective! So you are confronted with buyers who are ready to do anything to get their bonuses! Even if . . . this would mean that in 18 months, Globastic would be dead! (Because at the end of the day) they still will receive their bonuses!'

The cost reductions enacted by performance devices flowing through Mondialmaker's sourcing activities would result in price reductions that Globastic could not sustain; they would suffocate the supplier financially not only in relation to then current tasks but also for new possible tasks in the future. Once price reductions had become significant, the risk device changed 
Globastic's category and prevented it from getting high-value component orders. A manager from Globastic explained:

\begin{abstract}
'When you have a technical problem in a factory ... and this problem has consequences for our customers because we cannot deliver, Mondialmaker will first send you an invoice, and then they will send a team to take over... Then, they tell us to ... do this and do that! It will cost you an astronomical sum, and they will definitely not help you!'
\end{abstract}

Over time, such practices intensified and one of Globastic competing suppliers faced financial default, and this became a problem for Mondialmaker who could not afford losing the technology, skills in innovation and production processes possessed by the defaulted supplier; industrial knowledge might be lost in the exclusive pursuit of financialization.

When Mondialmaker realised such industrial risk, it attempted to fix the overflow by shifting work to Globastic from the supplier that by that time had already gone into liquidation. This happened even if the supply risk committee was 'not particularly enthusiastic about it!' Unfortunately, there was no other supplier that could take over the liquidated supplier's operations. There was no efficient market for this supply, as financialization would have predicted. The committee was in a difficult situation because it knew that Globastic might not financially capable of delivering the operations in question, but they needed Globastic's industrial expertise; hence, they suddenly placed industrial concerns over financial concerns. Thus, the committee was required to make the strange strategic choice of giving Globastic new innovation tasks to help it improve its financial viability. However, these new innovation tasks avoided the obligatory 
passage point of ROIC and Globastic taking on unprofitable orders. A quality manager explains as follows:

'The price of parts was defined based on the innovation ... costs supported by the strategic supplier.... These are high costs! (So when) Globastic said: "For these parts, I will require 2,000 hours of (innovation) resources" . . and thanks to our experience, we were aware that these parts required 3,000/3,500 hours of (innovation) resources . . I did not know how Globastic could manage!’

Engineers overlooked these industrial concerns since expressing their suspicions about Globastic would have been inconsistent with the demands of KPI Eng. In contrast, the performance device encouraged engineers to manage Globastic from a distance and to trust its capabilities to solve technical problems. Globastic was not a partner; it was a medium of short-term cost reduction.

Despite the risk that Globastic represented, it obtained new innovation tasks. Table 1 shows Globastic's risk ratings from 2003 to 2007 before and after negotiations, during which Globastic's managers agreed on producing unprofitable low-value components that, in return, would be compensated by projected forecast profits from high-value new orders. Globastic's negotiated risk rates were lower than those calculated by the risk devices.

INSERT TABLE 1 ABOUT HERE 
As an obligatory passage point, ROIC was enacted via performance targets and via risk rates used as a resource to negotiate postponement (Table 1). Relations of episodic power about sourcing decisions discarded industrial considerations of supply disruption from financialization judgements, creating friction and overflows within the network. They did so by requiring financial performance on the part of contracting suppliers that decreased those suppliers' profits, rendering them financially vulnerable and leading to industrial risk for the entire network. This tension will be considered more in the following section.

\section{Circuits of power in critical times: Financialization and the disruption of the global production network}

Mondialmaker's actual final demand dropped and, therefore, Globastic could not realise forecasted profits from newly awarded innovation tasks, but more problematically, it could not recover the investments made to develop the associated production tools. Globastic's chief executive officer explained as follows:

'Now if you wonder why we were in a delicate situation, well, we had invested astronomical amounts in international development, and then customers told us they would give us millions (of profits) from sourcing plans. Clearly, the crisis was coming, and we had the issue of re-financing our investments. When I say re-financing, I mean that every time we take on a sourcing plan today, we must ask ourselves if we have enough money to ... make the production tool investments while only seeing a return on this investment in five years' time.' 
Globastic's difficulties increased because Mondialmaker did not compensate Globastic for losses arising from investments that never transformed into actual orders. Globastic's chief executive officer continued:

'When you have a contract, (you have) a minimum amount of orders (that) guarantees that you put (some investments); (however) the manufacturer absolutely not contractually commits (to these) volumes. As I told you, on the contrary, suppliers must be fully engaged in terms of production capacity! . . . Finally, we invested $\mathrm{xx}$ million euros for a new production tool ... (that) was never needed! .. . They call this industrial risk!'

Final demand was under pressure, and categorisation and accounting devices collapsed when Mondialmaker was confronted with the problem of maintaining network flows while suppliers were defaulting. Financialization insisted on assuming that there would be a market for highly specialised suppliers, but there was not. It would have been excessively disruptive if Mondialmaker had simply allowed Globastic to go bankrupt.

Mondialmaker could not insource Globastic's activities since it was now devoid of its own competencies in production matters. Therefore, as explained by a purchasing manager, Mondialmaker's supply risk committee had to deal with heavy overflows that made categorisation and accounting devices weak. The success of the performance devices led to decreased costs, but risk devices responded by categorising Globastic as a level three or four risk (see Table 1). This categorisation would require blocking Globastic as a supplier. Instead, the committee ignored the 
risk device and considered investing economic resources in Globastic's operations. Obligatory passage points shifted. The industrial rationality of network interdependencies substituted ROIC as the obligatory passage point of circuits of power for a while.

\section{Circuits of power: The cost of restoring the global production network}

In the face of immediate financial collapse, Mondialmaker sustained Globastic's operations by means of extraordinary capital expenditures until other sourcing alternatives were found. Following Mondialmaker's financialized rationale when faced with a bankrupt supplier, the supply risk committee began looking for a new supplier willing to take over Globastic's operations. This process became intertwined with other wider macro processes whereby governmental agencies concerned with national economic attractiveness sought to maintain the national manufacturers' operations. The government established a 'fund for the modernisation of suppliers' through which the state and French MNCs, such as Mondialmaker, invested their capital to buy the equity of financially unstable suppliers. Globastic benefitted from such capital in exchange of $80 \%$ of its equity. An officer of Globastic explained that the fund was ultimately used by its clients to take part in Globastic's corporate governance. Consequently, the outcome of these wider episodic processes categorised suppliers as peripheries, reproducing shareholder rules of practice. The participation of Mondialmaker - via the fund - in corporate Globastic's governance decisions facilitated the tightening of the application of financialized rules of practices within Globastic.

\section{Discussion: Dynamisms of financialization}

Since the beginning of the century, rather than coordinating assembly operations, Mondialmaker regulated a decentralised production process within the global production network 
it operated. Its managerial devices - governed by accounting numbers - enacted obligatory passage points, ensuring the reproduction and stability of financialized relationships of episodic power (Clegg, 1989: 224-25). Financialization was made operational via the MNC's performance and risk devices. While performance devices demanded continuous sourcing efficiencies, leaving aside suppliers' need to make margins to survive, risk devices demanded financially robust suppliers. The devices contradicted each other, and they would be consistent with financialization only if the hypothesis of effective markets, in which suppliers could be easily substituted, was in place. Instead, pursuing financialization led to a crisis related to the network's competing, but hidden from performance devices, industrial-ideological rationality concerned technology, skills and competencies, which Mondialmaker had excluded from its devices but which turned out to be the Achilles heel of the arrangement. Table 2 recounts the circuits of power that explain this.

\section{INSERT TABLE 2 ABOUT HERE}

The circuits of power in Globastic's case were that financialization, as a mode of rationality, pressured Globastic but only in the sense of economic performance results; there was only limited concern about the industrial means that would be required from Globastic to achieve these results. The financialized system, therefore, had a blind spot, producing the tension that when it worked 'best' or 'as intended' it tended to fall apart and fail.

The case of Mondialmaker shows how an MNC is more than a 'network orchestrator' (Parkhe and Dhanaraj, 2003), and how processes of appropriation and distribution of value (Bair, 
2009) in financialized systemic and dispositional power turns an MNC into a regulator of a decentralised production process within the global production network it operates (De Marchi et al., 2014; Ponte and Sturgeon, 2014). The MNC's financialized systemic and dispositional powers mobilised obligatory passage points through which flows of episodic power had to pass. These financialized passageways made from accounting devices (Morgan, 2011) in which financial returns were the main target emptied Mondialmaker of its own competencies in production matters, leaving it to its network. This happened because the industrial rationalities of the network were left aside: suppliers were not categorised as competing entities (Ponte, 2014) but as mute objects. The space for market competition or value-adding chains shrunk to the benefit of complex political economic systems in which socio-political contexts shaped markets (Levy, 2008: 943).

For mainstream research on power and politics in MNCs, political processes were not just relational (Bouquet and Birkinshaw, 2008) but also embedded in institutional reproduction (Becker-Ritterspach and Dörrenbächer, 2011), flowing through both macro (Heidenreich, 2012) and micro conduits of circuits of power where each agency operated - among many others - in a highly complex environment of standing conditions and relationships that constituted them as actors in the same system (Clegg, 1989: 215). The case shows how the reproduction and discipline of financialized modes of rationality were made possible through fixed and stabilised fields of force mobilised by accounting devices (Cooper and Ezzamel, 2013; Miller and Power, 2013; Morgan and Kristensen, 2006; Quattrone and Hopper, 2005) that enacted obligatory passage points (Clegg, 1989: 224-25) within the network. These passageways frequently created relationships of episodic power (Becker-Ritterspach and Dörrenbächer, 2011) that were concerned with actors' categorisation within their networks (Dörrenbächer and Geppert, 2009; Fligstein, 1993; Kostova and Roth, 2003; Pettigrew et al., 2003). 
However, as the case shows, global production networks were contested interorganisational fields in which agencies struggled over the construction of economic relationships, governance structures, institutional rules and norms and discursive frames (Hardy et al., 1998; Maguire et al., 2004). Performance and risk devices made passageways 'contingent upon what flows through the circuits' (Clegg, 1989: 224), so when overflows flew out of political processes, fixed and stabilised financialized fields of force were challenged by a competing, yet to financialization, invisible and hidden mode of industrial rationality concerning network interdependencies, innovation and technological needs. Instead of reproducing rules fixing collaborative relationships of meanings and membership, accounting devices produced tensions. They did so through risk devices that required economic performance on the part of contracting suppliers, which decreased those suppliers' profits, rendering them financially vulnerable and leading to industrial risk for the entire supply chain. While power over suppliers may be on the side of Mondialmaker, it is not clear that they controlled the network. Dispositional and facilitative powers are uncertain prerequisites for controlling activities. Control is more than, or at least different from, power.

\section{Conclusion}

So, how are political processes informed and conditioned by categorisation and accounting devices that mediate financialization processes in the global production network?

The case of Mondialmaker shows that financialization is a practice that reproduces rules of meanings and memberships; it requires framing and the operationalisation of techniques of discipline to make its dominant modes of rationality pervasive across episodes. However, there is a limit to this domination of financialization. It creates overflows because it cannot completely 
dominate a hidden industrial rationality that focuses on innovation, materiality and production. The financialized system, therefore, has a blind spot, producing the surprising observation that when it works 'best' or 'as intended', it tends to fall apart and become difficult. Therefore, dispositional and facilitative powers are unruly resources. As shown in the case of Mondialmaker, when financialization functions well, suppliers are treated as 'competitors' and are pressured to reduce costs. However, this is at the detriment of the survivability of suppliers whose bankruptcy will disrupt the entire global production network that the MNC depends on to survive. This disruption, in turn, is costly.

The paradox is that financialized accounting devices developed to contain costs may, since risk increases, increase costs. The costs of operating financialization are not accounted for by fixing meanings and memberships. These costs are removed from political processes, even if people are privately aware of them. Therefore, accounting devices underscore the financialization mode of rationality only under conditions where contradiction has not turned into crisis. However, when crisis occurs, these accounting devices have little power, and costly processes that primarily take technology, skill and capability into account rectify the situation.

Hence, financialization devices are ambiguous; they are not inherently facilitative of systemic powers but gain power only when their overflows and tensions can be rectified and silenced as a practical matter. When overflows become heavy, financialized devices are much weaker. When overflows are small or non-existent, financialization may fix ambiguous political processes; when overflows are significant, then financialization is pitiful and may be substituted by other devices, such as those from the industrial economy that will operate at least for a time. This substitution is why political processes can assume many different shapes and directions, as the case of Mondialmaker shows. 
Consequently, the case of Mondialmaker shows how systemic power is never eternal (Clegg, 1989: 2015), but instead is dynamic when overflows appear in the outcomes of episodic political processes. Perhaps the real irony is that the two accounting devices contradicted each other, and this contradiction added fuel to the processes of contradiction and conflict. Thus, financialized accounting devices may contribute to tensions and disruption rather than mediate and resolve them.

\section{Acknowledgements}

We are most grateful to the productive and helpful advice provided by Professor Stuart Clegg and insightful suggestions by two other guest editors of the special issue (as well as the anonymous reviewers). These have been instrumental in developing the paper.

\section{Funding}

This research received no specific grant from any funding agency in the public, commercial, or not-for-profit sectors.

\section{Notes}

${ }^{1}$ In an industrial economy - the type of business of our case study - those matters are innovation, technology and skills.

${ }^{2}$ Overflows could also be positive. An example is the successful hand dryer that was invented from airplane turbines. 


\section{References}

Alvesson M (2003) Methodology for close up studies-struggling with closeness and closure. Higher Education 46(2): 167-93.

Andersson U, Forsgren M and Holm U (2007) Balancing subsidiary influence in the federative MNC: A business network view. Journal of International Business Studies 38(5): 802-18.

Bair J (2009) Global commodity chains: Genealogy and review. In: Bair J (ed) Frontiers of Commodity Chain Research. Stanford, CA: Stanford University Press, 1-34.

Baunsgaard VV and Clegg S (2012) Dominant ideological modes of rationality: Organizations as arenas of struggle over members' categorization devices. In: Rethinking Power in Organizations, Institutions, and Markets. Research in the Sociology of Organizations (34): 199-232.

Becker-Ritterspach F and Dörrenbächer C (2011) An organizational politics perspective on intrafirm competition in multinational corporations. Management International Review 51(4): 533-59. Blazejewski S (2009) Actors' interests and local contexts in intrafirm conflict: The 2004 GM and Opel crisis. Competition and Change 13(3): 229-50.

Bouquet C and Birkinshaw J (2008) Weight versus voice: How foreign subsidiaries gain attention from corporate headquarters. Academy of Management Journal 51(3): 577-601.

Boyer R (2005) From shareholder value to CEO power: The paradox of the 1990s. Competition and Change 9 (1): 7-47.

Callon M (1998) An essay on framing and overflowing: Economic externalities revisited by sociology. Sociological Review 46(S1): 244-69.

Callon M, Rip A and Law J (1986) Mapping the Dynamics of Science and Technology: Sociology of Science in the Real World. London: Macmillan. 
Cerny PG (1997) Paradoxes of the competition state: The dynamics of political globalization. Government and Opposition 32(2): 251-74.

Clegg S (1989) Frameworks of Power. London: Sage Publications.

Clegg SR, Carter C, Kornberger M and Schweitzer J (2011) Strategy: Theory and Practice. London: Sage Publications.

Clegg SR, Courpasson D and Phillips N (2006) Power and Organizations. London: Pine Forge Press.

Coe NM and Yeung HWC (2015) Global Production Networks: Theorizing Economic Development in an Interconnected World. Oxford: Oxford University Press.

Cooper DJ and Ezzamel M (2013) Globalization discourses and performance measurement systems in a multinational firm. Accounting, Organizations and Society 38(4): 288-313.

Courpasson D, Golsorkhi D and Sallaz JJ (2012) Rethinking power in organizations, institutions, and markets: Classical perspectives, current research, and the future agenda. Research in Sociology of Organizations 34(34): 1-20.

De Marchi V, Di Maria E and Ponte S (2014) Multinational firms and the management of global networks: Insights from global value chain studies. In: Pedersen T, Venzin M and Devinney TM (eds) Orchestration of the Global Network Organization. Bingley: Emerald Group Publishing Limited, 463-86.

Dörrenbächer C and Geppert M (2009) A micro-political perspective on subsidiary initiativetaking: Evidence from German-owned subsidiaries in France. European Management Journal 27(2): 100-12.

Epstein GA (2005) Introduction: Financialization and the world economy. In: G. A. Epstein (eds) Financialization and the World Economy. Cheltenham and Northampton: Edward Elgar, 3-16. 
Ezzamel M, Lilley S and Willmott $\mathrm{H}$ (2004a) Accounting representation and the road to commercial salvation. Accounting, Organizations and Society 29(8): 783-813.

Ezzamel, M, Willmott $\mathrm{H}$ and Worthington F (2004b) Accounting and management-labour relations: The politics of production in the 'factory with a problem.' Accounting, Organizations and Society, 29(4): 269-302.

Ezzamel M, Willmott H and Worthington F (2008) Manufacturing shareholder value: The role of accounting in organizational transformation. Accounting, Organizations and Society 33(2-3): 10740.

Fligstein N (1993) The Transformation of Corporate Control. Cambridge, MA: Harvard University Press.

Foucault M (1981) 1981: Subjectivité et Vérité. Résumé des Cours, 1970-1982. Conférences, Essais et Lessons du Collége de France: 134.

Froud J, Haslam C, Johal S and Williams K (1998) Breaking the chains? A sector matrix for motoring. Competition and Change 3(3): 293.

Froud J, Haslam C, Johal S and Williams K (2000) Shareholder value and financialization: Consultancy promises, management moves. Economy and Society 29(1): 80-110.

Froud J, Johal S, Leaver A and Williams K (2006) Financialization and Strategy: Narrative and Numbers. London: Routledge.

Froud J, Johal S, Leaver A and Williams K (2014) Financialization across the Pacific: Manufacturing cost ratios, supply chains and power. Critical Perspectives on Accounting 25(1): $46-57$.

Ghoshal S and Bartlett CA (1988) Creation, adoption, and diffusion of innovations by subsidiaries of multinational corporations. Journal of International Business Studies 19(3): 365-88. 
Gill S (1995) Globalisation, market civilisation, and disciplinary neoliberalism. Millennium 24(3): $399-423$.

Goyer M (2001) Corporate governance and the innovation system in France 1985-2000. Industry and Innovation 8(2): 135-58.

Hardy C, Phillips N and Lawrence T (1998) Distinguishing trust and power in interorganizational relations: Forms and facades of trust. In: Lane $\mathrm{C}$ and Bachmann $\mathrm{R}$ (eds) Trust Within and Between Organizations. Oxford: Oxford University Press, 64-87.

Heidenreich M (2012) The social embeddedness of multinational companies: A literature review. Socio-Economic Review 10(3): 549-79.

Holm U, Holmström C and Sharma D (2005) Competence development through business relationships or competitive environment? Subsidiary impact on MNC competitive advantage. Management International Review 45(2): 197-218.

Kostova T and Roth K (2003) Social capital in multinational corporations and a micro-macro model of its formation. Academy of Management Review 28(2): 297-317.

Kreiner K and Mouritsen J (2005) The analytical interview. In: Tengblad S, Solli R and Czarniawska B (eds) The Art of Science. Copenhagen: CBS Press, 153-76.

Kristensen PH and Zeitlin J (2001) The making of a global firm: Local pathways to multinational enterprise. In: Kristensen P, Morgan G and Whitley R (eds) The Multinational Firm: Organizing Across Institutional and National Divides. Oxford: Oxford University Press, 172-95.

Latour B (1986) Visualisation and cognition: Drawing things together. In: Kuklick H (ed) Knowledge and Society: Studies in the Sociology of Culture and Present. Greenwich, CT: Jai Press, $1-40$. 
Latour B (1991) Technology is society made durable. In: Law J (ed) A Sociology of Monsters. London: Routledge, 103-31.

Latour B (2005) Reassembling the social: An introduction to actor-network-theory. New York: Oxford university press.

Levy DL (2008) Political contestation in global production networks. Academy of Management Review 33(4): 943-63.

Maguire T, Hogan D, O’Donoghue J, McQuade E and Murphy E (2004) The competencies for next generation employability. Journal of European Industrial Training 29(6): 425-35.

Miller PB and Power M (2013) Accounting, organizing and economizing: Connecting accounting research and organization theory. Academy of Management Annals 7(1): 557-605.

Morgan G (2011) Reflections on the macro-politics of micro-politics. In: Dörrenbächer C and Geppert M (eds) Power and Politics in the Multi-National Corporation: The Role of Institutions, Interests and Identities. New York, NY: Cambridge University Press, 415-36.

Morgan G and Kristensen PH (2006) The contested space of multinationals: Varieties of institutionalism, varieties of capitalism. Human Relations 59(11): 1467-90.

Morin F (2000) A transformation in the French model of shareholding and management. Economy and Society 29(1): 36-53.

Mudambi R and Navarra P (2004) Is knowledge power? Knowledge flows, subsidiary power and rent-seeking within MNCs. Journal of International Business Studies 35(5): 385-406.

Mueller F (1996) Human resources as strategic assets: An evolutionary resource-based theory. Journal of Management Studies 33(6): 757-85. 
Mueller F and Purcell J (1992) The Europeanization of manufacturing and the decentralization of bargaining: Multinational management strategies in the European automobile industry. International Journal of Human Resource Management 3(1): 15-34.

Muniesa F, Millo Y and Callon M (2007) An introduction to market devices. In: Callon M, Millo Y and Muniesa F (eds) Market devices. Oxford: Oxford University Press, 1-12.

Oliveira J and Clegg S (2015) Paradoxical puzzles of control and circuits of power. Qualitative Research in Accounting and Management. 12(4): 425-51.

Palpacuer F, Seignour A and Vercher C (2011) Financialization, globalization and the management of skilled employees: Towards a market-based HRM model in large corporations in France. British Journal of Industrial Relations 49(3): 560-82.

Parkhe A and Dhanaraj C (2003) Orchestrating globally: Managing the multinational enterprise as a network. Leadership in International Business Education and Research 8: 197-214.

Pettigrew AM, Whittington R, Melin L, Sanchez-Runde C, Van den Bosch FA, Ruigrok W and Numagami T (2003) Innovative Forms of Organizing: International Perspectives. London, Sage.

Piotti G (2009) Cost reduction through relocation, or the construction of myths in discourse. Competition and Change 13(3): 305-26.

Piven FF and Cloward RA (1997) The Breaking of the American Social Compact. New York, NY: New Press.

Ponte S and Sturgeon T (2014) Explaining governance in global value chains: A modular theorybuilding effort. Review of International Political Economy 21(1): 195-223. 
Quattrone P and Hopper T (2005) A 'time-space odyssey': Management control systems in two multinational organisations. Accounting, Organizations and Society 30(7-8): 735-64.

Ruigrok W and van Tulder R (1995) The Logic of International Restructuring. London: Routledge. Sacks H (1972) An initial investigation of the usability of conversational data for doing sociology. In: Sudnow, DN (ed) Studies in Social Interaction. New York, NY: Free Press, 31-74.

Sawyer M (2013) What is financialization? International Journal of Political Economy 42(4): 518.

Townley B (1993) Foucault, power/knowledge, and its relevance for human resource management. Academy of Management Review 18(3): 518-45.

Van der Zwan N (2014) Making sense of financialization. Socio-Economic Review 12(1): 99-129.

Wieviorka M (2009) Violence: A New Approach. London: Sage Publications.

Table 1. Globastic's calculated and negotiated risk ratings 2003-2007

\begin{tabular}{|l|l|l|l|l|l|}
\hline$\square$ & $\square \mathbf{2 0 0 3}$ & $\square \mathbf{2 0 0 4}$ & $\square \mathbf{2 0 0 5}$ & $\square \mathbf{2 0 0 6}$ & $\square \mathbf{2 0 0 7}$ \\
\hline$\square$ Calculated globastic risk ratings & $\square 3$ & $\square 2$ & $\square 3$ & $\square 4$ & $\square 4$ \\
\hline$\square$ Negotiated globastic risk ratings & $\square 2$ & $\square 2$ & $\square 2$ & $\square 3$ & $\square 3$ \\
\hline
\end{tabular}


Table 2. Circuits of power in Mondialmaker's global production network. Adapted from Clegg's circuits of power framework (1989)

\begin{tabular}{|c|c|c|c|c|c|c|}
\hline \multirow{2}{*}{$\begin{array}{l}\square \text { Systemic } \\
\text { power }\end{array}$} & \multicolumn{2}{|c|}{$\begin{array}{l}\square \text { Dispositional power } \\
\square \text { flowing from Mondialmaker }\end{array}$} & \multicolumn{4}{|c|}{$\square$ Relationships of episodic power } \\
\hline & $\begin{array}{l}\square \text { Rules fixing } \\
\text { relationships of } \\
\text { meaning and } \\
\text { membership }\end{array}$ & $\begin{array}{l}\square \text { Obligatory passage } \\
\text { points }\end{array}$ & $\square$ & $\square$ Agencies & $\begin{array}{l}\square \text { Means } \\
\text { controlling } \\
\text { resources }\end{array}$ & $\square$ Outcomes \\
\hline \multirow[b]{4}{*}{ 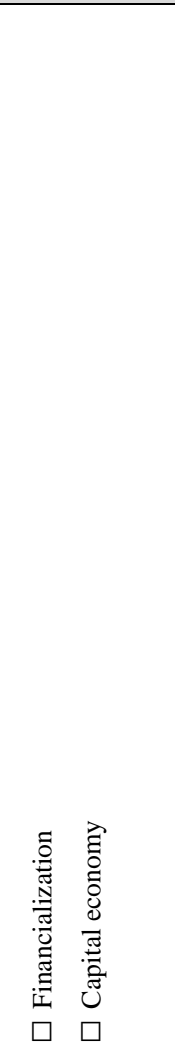 } & \multirow{4}{*}{$\begin{array}{l}\text { Accounting devices } \\
\square \text { defining } \\
\text { performance } \\
\square \text { \& risk } \\
\square+ \\
\square \text { categorisation } \\
\text { devices establishing } \\
\text { hierarchical links that } \\
\text { overlap with } \\
\text { functional link }\end{array}$} & \multirow[b]{4}{*}{$\begin{array}{l}0 \\
0 \\
\frac{0}{n} \\
0 \\
\vdots \\
\sum \\
\square \\
\square\end{array}$} & \multirow{3}{*}{ 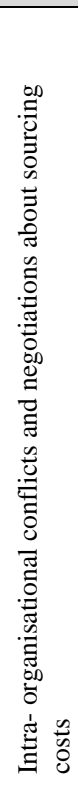 } & $\begin{array}{l}\square \text { Purchasing } \\
\text { managers concerned } \\
\text { with sourcing costs of } \\
\text { low-value components } \\
\square \text { KPI Purch }\end{array}$ & \begin{tabular}{|l|} 
Control over \\
suppliers' \\
relationships. \\
Control over \\
suppliers' \\
risk ratings \\
\end{tabular} & $\begin{array}{l}\square \text { Sourcing costs of low- } \\
\text { value components: corporate } \\
\text { controllers \& purchasing } \\
\text { managers power over } \\
\text { engineers and quality } \\
\text { managers }\end{array}$ \\
\hline & & & & $\begin{array}{l}\text { Engineers and } \\
\text { quality managers } \\
\text { concerned with high- } \\
\text { value components } \\
\text { costs } \\
\square \text { KPI Eng }\end{array}$ & \begin{tabular}{|l|} 
Expertise, \\
knowledge \\
of production \\
processes, \\
control over \\
information \\
power over \\
the \\
validations \\
of high-value \\
components \\
sourcing \\
\end{tabular} & $\begin{array}{l}\text { In risked sourcing costs } \\
\text { of low-value components: } \\
\text { engineers and quality } \\
\text { managers power over } \\
\text { purchasing managers }\end{array}$ \\
\hline & & & & $\begin{array}{l}\text { Corporate controllers } \\
\text { concerned with } \\
\text { products' total costs } \\
\square \text { KPI Comm }\end{array}$ & $\begin{array}{l}\text { Initiative to } \\
\text { begin and } \\
\text { close the } \\
\text { product } \\
\text { budget } \\
\text { process } \\
\end{array}$ & $\begin{array}{l}\square \text { In sourcing costs of high- } \\
\text { value components: engineers } \\
\text { and quality managers power } \\
\text { over purchasing managers }\end{array}$ \\
\hline & & & \multirow{2}{*}{ 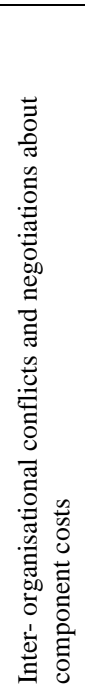 } & $\begin{array}{l}\square \text { Suppliers } \\
\square \text { Concerned with } \\
\text { high-value components } \\
\text { orders }\end{array}$ & $\begin{array}{l}\text { Technology, } \\
\text { innovation, } \\
\text { skills, } \\
\text { production } \\
\text { tools }\end{array}$ & $\begin{array}{l}\square \text { In risked sourcing } \\
\text { episodes: risky suppliers } \\
\text { power over manufacturer on } \\
\text { sourcing of low-value } \\
\text { components so that suppliers } \\
\text { get cost increases and new } \\
\text { high-value components } \\
\text { orders }\end{array}$ \\
\hline 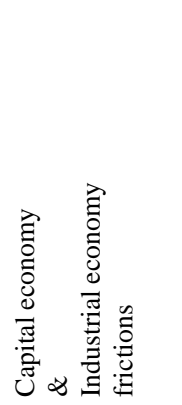 & $\begin{array}{l}\square \text { Industrial devices } \\
\text { concerned with } \\
\text { interdependencies, } \\
\text { technology and skills } \\
\text { within the global } \\
\text { production network. }\end{array}$ & 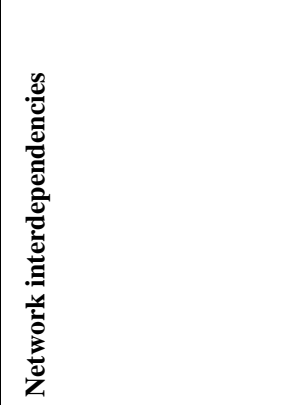 & & $\begin{array}{l}\square \text { Governmental } \\
\text { agencies }\end{array}$ & $\begin{array}{l}\square \text { Economic } \\
\text { attractiveness } \\
\text { of the } \\
\text { national } \\
\text { production } \\
\text { network }\end{array}$ & $\begin{array}{l}\square \text { In risked sourcing } \\
\text { episodes: the State and } \\
\text { French MNC - via an } \\
\text { investment fund - obtain } \\
\text { corporate governance rights } \\
\text { in suppliers' firms in } \\
\text { exchange for equity capital. }\end{array}$ \\
\hline
\end{tabular}


Isabel Pedraza-Acosta works as an assistant professor at Copenhagen Business School. Before joining CBS in 2013, Isabel received a PhD in Accounting, Management Control \& Organizations at HEC Paris. Her work examines the mediating role of accounting devices in inter and intra organizational practices. She combines diverse sociological based theory on individual and organizational practices (economic sociology, economics of convention, pragmatic sociology, stigmatization) using immersive methods. [ipa.om@cbs.dk]

Jan Mouritsen is professor at Copenhagen Business School. His interests concern the role of Management Technologies in various organisational and social contexts. His research focuses on the sociology of calculative arrangements and the constitution of organisation, value and production drawing on practice based theory. His interests include Intellectual Capital and Knowledge Management, Technology Management, Operations Management and Management Control. He has published in journals including Accounting, Organizations and Society; Management Accounting Research; Scandinavian Journal of Management; Accounting, Auditing and Accountability Journal; Journal of Intellectual Capital and Critical Perspectives on Accounting. (jm.om@cbs.dk)

\section{Corresponding Author:}

Isabel Pedraza-Acosta

Operations Management

Copenhagen Business School

Solberg Plads 3 Frederiksberg 2000

Denmark

ipa.om@cbs.dk

\section{Other Author(s):}

Jan Mouritsen 
Operations Management

Copenhagen Business School

Solberg Plads 3 Frederiksberg 2000

Denmark

jm.om@cbs.dk 